\title{
Dynamics of Young Indian Consumers' Buying Behaviour Towards Branded Apparels: Gender Perspective
}

\author{
Dr. Namita Rajput \\ Department of Commerce. Sri Aurobindo College \\ University of Delhi, India \\ Ms. Akanksha Khanna \\ School of Management Studies. IGNOU, Delhi, India \\ akankshakh@gmail.com
}

\begin{abstract}
Consumer market for fashion apparel has become more varied by in surge of designer brands, store brands, personalization and advertisements in the global market place of today. There is an increase in positive attitude towards western brands. Over the past decade, the fashion industry has gone through some major structural changes. This study examines the insights of gender perspective and throws light on shopping habits, brand awareness, brand preference of young consumers in the apparels segment. It focuses on the differences in the shopping orientations of male and female shoppers with respect to the various buying behaviour dimensions divided into five attributes i.e. Store Attributes, Product attributes, Reference Groups, Consumer characteristics and Promotional factors.The results gathered can be a useful ingredient for the marketer to strategize on the basis of gender perspective.
\end{abstract}

Keywords: Gender perspective, Shopping Behaviour, Young consumers, Branded Apparels, Store Attributes, Product Attributes, Consumer Characteristics, Reference Groups, Promotional Factors

\section{INTRODUCTION}

The apparel and clothing industry being positioned at first place and also the spending on apparel and clothing among the customers are getting increased day by day; it becomes imperative to study the changing behaviour of consumers. Over the past decade, the fashion industry has gone through some major structural changes. In the fast evolving fashion industry, even the best of plans and activities can be undermined by economic changes and actions of competitors. But what is challenging in nature is the fashion trend cycles that are accelerating as nowadays the average successful clothing trend lasts for a very short span of time i.e. 6-12 weeks and hence to gain from the situation is more difficult. There is a clear understanding amongst the retailers that a complete view of the target consumers is very helpful in ornamenting shopping propensity.

Traditionally, Indians preferred dresses stitched by local tailors catered exclusively to local demand. The growing awareness of brands since 1980s and the convenience offered by readyto-wear garments were largely responsible for the development of the branded apparel industry in India (Indian Retail Report 2013). Other factors affecting to its growth are considered as better purchasing power in the hands, access to fashion trends outside the country, and the superior quality of fabrics available in the fashion market. 1990s witnessed a drastic change in the overall economic environment of the country which is described liberal 
trade and new investment policies. It was seen the effects of such liberalized polices in the clothing industry also. After liberalization of Indian economy, there emerged more than 100 leading brands that jostled for consumer mind space. Today, Indians are more inclined than consumers in other markets to buy apparel for a specific purpose. Indeed, 38 percent of Indian respondents to a recent McKinsey study said they were highly likely to buy apparel for special events, a significantly higher proportion as compare to Brazil (5\%), Russia (3\%) or China (6\%). The growth of the Indian and global fashion designers has encouraged the branded apparel market additionally.

The purpose of this study is to investigate buying behaviour which constitutes buying behaviour dimensions and shopping habits as regards young Indian consumers in the age group of 18-25 years. In this competitive era marketer must be fully aware about the customer needs distinctly and separately as two groups males and females as regards what are they expecting from a brand, how they differ in their buying behaviour, factors which push them to purchase a particular brand, their total outlay, shopping frequency etc. to attain a competitive edge. This vital information can help the companies to formulate the strategies as per the customer needs \& deliver them the products which consumer want from the company which will be profitable for the company embedding gender perspective. Retailers and marketers should understand the immense diversity among consumers if they are to market apparel accurately and successfully.

\section{REVIEW OF LITERATURE}

Personal factors modify how a male or female is perceived and the most important personal factor is the consumer personality. Personality is a dynamic concept which changes with the life has gone, describing the growth and development of human psychological setup which also differ on gender aspect. Most of the time products project a "personality" or an image that has an appeal to the consumer, with which consumer (he or she) can relate to. The point that is important from marketing point of view is, given the consumer's different and distinct personality traits concerning gender issue, the marketer should be able to identify these differences and its influence on the buying behaviour. Along with many basic differences of their personality, the personal factors which affect the perception of a consumer are the occupation, economic status, age, education and social life. The new brand or style in outfit can be perceived as a necessity, luxury or a super luxury product depending upon the awareness and attitude towards particular item which depend on anyone of the above or the association of two or more. Many studies have given insights about gender difference in building relationships with brands.

According to Chen-Yu and Seock (2002), the "fundamental segmentation of the clothing market is based on gender", and gender therefore plays a vital role in influencing a consumer's clothing selection and apparel buying behaviour (Bohdanowicz and Clamp 1994 cited in ChenYu and Seock 2002). Shopping is even described by Dholakia (1999:) as a "gendered activity". The results revealed by these studies magnify the role of women in judgment of a brand and consider women as an active partner than men in buying behaviour.

The retail market in developed countries of the world was at the mature stage (Berner et. al., 2001). Intense competition and sluggish population growth was motivating leading apparel brands of the world to enter in new markets and attract new customers (Steenkamp and Hofstede, 2002). The emergence of economies particularly India with strong middle class was impelling these apparel firms' to ensure their presence in such economies (Dickson et. al., 2004). 
Clothing is one of the consumer products that are vulnerable to fashion dynamics and sways making it important for the marketers to test whether consumer loyalty to the brands has changed. In sports apparel, loyalty is a vital construct in strategic marketing. Studies such as (Hu, et al.,2010) show that in competitive repeat-purchase markets, loyalty is shaped more by the passive acceptance of brands than by strongly held attitudes about them. Wearing clothes is often regarded as a habitual and everyday practice. However, apparel has been used not only to meet basic human needs (e.g., protecting from the elements) but also to communicate identities (Postrel, 2003). Wearing clothing is one of the ways in which people construct their identities and have their identities shaped by others (Davis, 1984; Kaiser, 1985; McCracken, 1988; Roach-Higgins \& Eicher, 1992; Stone, 1962).

Shopping behaviour is a complex and multidimensional concept. Defining shopping orientation is extremely difficult, due to numerous interrelated variables. Although the concept shopping orientation is described by researchers from various perspectives, certain major variables (or concepts) are repeated in the different description. Stone (1954) introduced the concept shopping orientation. He referred to shopping lifestyles or shoppers" styles that place emphasis on certain activities in particular. Other researchers added to this definition by pointing out that shopping-specific lifestyles encompass shopping activities, interests, and opinions. The definitions of shopping orientation reflect a view of shop-ping as a complex personal, economic, social and recreational phenomenon (Darden and Howell, 1987; Shim and Kotsiopulos 1993). Shoppers with different shopping orientations reveal different consumer characteristics and differences in market behaviour, including different needs and preferences for information sources, store preferences and store attributes (Shim and Kotsiopulos, 1992).

\section{Conceptual Framework}

\section{CONCEPTUAL FRAMEWORK AND RESEARCH OBJECTIVES}

On the basis of the previous studies undertaken in this area, a number of factors have been identified which affect the perception of customers in respect of brands and consequently their evaluation. These factors have been incorporated in the current study as five dimensions of buying behaviour model which influence the purchase intentions of the customer. These include store attributes, product attributes, Reference groups, consumer characteristics and promotional factors.

\section{Store Attributes}

Store attributes are the store atmospherics and characteristics like facilities in the store, services provided by the store, store format etc. which influence the consumer apparel buying behaviour. (Gurunathan, 2013). The retail stores play major role in influencing consumers for both store and manufacturer's brands. Attitude toward promoted brands is characterized by positive store image, smart shopper self-perception, need for affiliation, and money attitude regarding power-prestige and anxiety. However, attitude of consumers towards store brands is determined by more positive store image, price advantage, range of products to exercise buying options, loyalty and trust related factors (Liu and Wang, 2008). In the present study, this attribute comprises variety, post transaction services, services by staff, physical facilities and membership facilities.

\section{Product Attributes}

Product attributes are the product feature such as product quality, price, style, design, colour etc. Kwan et al (2004) identified five factors in clothing choice criteria viz. named product and self-image related criteria, style and quality related criteria, durability and easy care, fit and sex appropriateness, and price. Product quality refers to the features or characteristics of a 
product or service that is able to satisfy the stated or implied customer needs. In other words, product quality can be defined as "fitness for use" or "conformance to requirement" (RussellBennett, McColl-Kennedy \& Coote, 2007). In this study, product attribute dimension includes price, fit, quality, style and durability

\section{Reference Groups}

The youth of today generally seek acceptance from their peers to boast their self-confidence and to blend with their social surrounding. Reference groups are the external influencers like television programmes, magazines, consumers' favourite celebrities or stars, friends, family members, other persons etc. who influence the apparel buying behaviour of the consumers. This dimension in the present study is measured by influence of family and friends, past experience, Internet, TV/Magazines and Celebrity influence

\section{Consumer Characteristics}

Consumer characteristics approach seemed to be the most powerful and explanatory as it focused on the mental orientation of consumers in making decisions. Consumer characteristics are the consumer attributes like involvement, fashion $\&$ brand consciousness, loyalty, emotion etc. which differs from consumer to consumer and also have effect on apparel buying behaviour. In this study this dimension is measured under the indicators viz. fashion consciousness, store image, impulsive buying behaviour, brand loyalty, and preference to wear and try before purchase.

\section{Promotional Factors}

These are the various promotional techniques used by the marketer to attract a large consume base. Duncan (2005) states that advertising has historically been the main communication choice for marketers as it can quickly increase brand awareness and brand knowledge though advertising impact is difficult to measure. Advertising plays a conspicuous role in marketing as it operates more visibly than other marketing variables (Eadie et al., 1999). In the present study, this dimension includes pricing techniques, social media, in- store promotions, celebrity endorsements, and visual display.

\section{Research Objectives}

The present study seeks to investigate the buying behaviour which constitutes: buying behavior dimensions, shopping habits such as shopping expenditure and frequency giving a gender perspective view and examine different factors influencing young consumers buying behaviour in apparel retail segment. .

This objective has been categorized into following sub-objectives as listed hereunder.

1. To identify the differences in buying behavior dimensions between males and female

2. To identify the differences in shopping expenditure between males and females

3. To identify the differences in shopping frequency between males and females

To achieve the above objectives following hypotheses were formed:

$\mathrm{H}_{1:}$ Males and females carry out differences in their buying behaviour dimensions.

$\mathrm{H}_{2:}$ Males and females carry out differences in their shopping expenditure

$\mathrm{H}_{3}$ : Males and females carry out differences in their shopping frequency

\section{Rationale Of The Study}

As suggested by Maslow's hierarchy of needs, all humans have a need for clothing, whether to satisfy a physiological need, for both privacy and protective reasons, or in order to meet needs related to esteem and belongingness (Hawkins, Mothersbaugh and Best 2007). Thus, some 
money will be spent throughout their lifetime on the purchase of various garments to satisfy these needs (Hawkins et al. 2007). It is, therefore, useful to investigate the capital-and peopleintensive, substantial clothing industry of India, particularly in terms of the branded apparel buying behaviour of young consumers in the age group of 18-25 years. The need for this research is due to the multifaceted and complex nature of the shopping habits with regards to these consumers, especially within a multicultural society such as India.

These insights of young consumer behavior will be imperative in strategy formulation and facilitate to gain from the situation which is instrumental in increasing the turnover. This segment of society i.e. young consumers is very important group amongst all the groups in the society because major purchases in the family, is done for this segment and revolves around this segment. This makes it all the more important to understand the psychology, mindset, motivators, satisfiers and dissatisfiers. The target segment was selected looking at the Indian existing and expected demographics which serves as a major clientele to the apparel industry in India. Today's teenagers are not only a more powerful segment but probably one of the most profitable. Within Generation Y, a sub-generation, referred to as the "Twixters" and aged 18 to 25 , has been identified and referred to as a "larger phenomenon" in today's society (Grossman 2005). Grossman (2005) explains that, "in the past, people moved from childhood to adolescence and from adolescence to adulthood, but today there is a new, intermediate phase along the way. The years from 18 until 25 and even beyond have become a distinct and separate life stage, a strange, transitional never-never land between adolescence and adulthood in which people stall for a few years". The individuals caught up in this so-called pause in the natural progression of life are referred to as being "betwixt and between", hence the name "Twixters" (Grossman 2005). This subgroup of Generation Y, which accounts for over one-third of this generation (Martin and Turley 2004), is thus the chosen sample of this study.

\section{RESEARCH METHODOLOGY}

The present study is based on a sample frame of 500 respondents consisting of students and working professionals of Delhi/NCR, Bangalore and Chandigarh area in the age group of 18-25 years. The questionnaire was self-administered in the colleges and was also sent through emails and social networking sites like Facebook and linked in. Five hundred and fifty questionnaires were distributed but five hundred questionnaires were elucidated and used for the final analysis after eliminating those that were partially completed.

The final questionnaire comprised of 3 parts with a total of 35 questions. Section I of the questionnaire contained 4 questions on demographic factors of the respondents including gender, Age, Education and Occupation. Section II of the questionnaire consists of 6 questions on Branded apparels and shopping habits including Brand awareness, brand preferences, place preference, shopping for special occasions, shopping frequency and shopping expenditure. Section III of the questionnaire contained 25 questions relating to 25 traits corresponding to 5 apparel buying behaviour dimensions viz., Store Attributes (Services by staff, Membership facilities, Physical facilities, Post transaction services, Variety), Product Attributes (Fit, Durability, Style, Price, Quality) ,Reference Groups (Influence of family and friends, celebrity influence, Past Experience, TV/magazines, Internet), Consumer characteristics (Fashion consciousness, Preference to wear and try before purchase, Impulse buying behaviour, Store image, brand loyalty) and Promotional factors( Social media, In- store promotions, pricing techniques, visual displays, Celebrity endorsements).All these questions were measured with a 5 point Likert Scale that ranged from strongly disagree (1) to strongly agree (5). 
The empirical results and analysis have been presented section wise. In the first section, Reliability and Equivalence of Various Items in Apparel Buying Behaviour Dimensions was determined by observing Cronbach's alpha values. The second section is emphasizing on general information about respondents in terms of their Brand awareness, Brand preference, shopping frequency and shopping expenditure and other shopping habits.

In the third section, differences in buying behavior dimensions between males and females have been analyzed. Lastly, in the Fourth section differences in Shopping expenditure and shopping frequency between males and females have been evaluated.

\section{DATA ANALYSIS AND INTERPRETATIONS}

\section{Demographic Descriptive}

Table 1 below shows that 64percentage of respondents were females, 36 percent were in the age group of 21-24 years, 44 percent were under graduates and 64 percent were students.

Table 1 Demographic descriptive

\begin{tabular}{|c|c|c|c|c|}
\hline \multicolumn{2}{|l|}{ Demographics } & Frequency & Percentage & Cumulative Percentage \\
\hline \multicolumn{5}{|l|}{ GENDER } \\
\hline & Male & 178 & 36 & 36 \\
\hline & Female & 322 & 64 & 100 \\
\hline & Total & 500 & 100 & \\
\hline \multicolumn{5}{|l|}{ AGE } \\
\hline & $18-21$ & 321 & 64 & 64 \\
\hline & $21-25$ & 179 & 36 & 100 \\
\hline & Total & 500 & 100 & \\
\hline \multicolumn{5}{|l|}{ EDUCATION } \\
\hline & UG & 221 & 44 & 44 \\
\hline & $\mathrm{PG}$ & 170 & 34 & 78 \\
\hline & Above PG & 109 & 22 & 100 \\
\hline & Total & 500 & 100 & \\
\hline \multicolumn{5}{|l|}{ OCCUPATION } \\
\hline & Student & 318 & 64 & 64 \\
\hline & Employee & 112 & 22 & 86 \\
\hline & Self employed & 70 & 14 & 100 \\
\hline & Total & 500 & 100 & \\
\hline
\end{tabular}

\section{Reliability Analysis}

Reliability and Equivalence of Various Items in Apparel Buying Behaviour Dimensions was determined and Cronbach's alpha values were observed.

From the Table 2 below, all the five dimensions of buying behaviour i.e. store attributes, product attributes, reference groups, consumer characteristics and promotional factors achieved a high Cronbach's alpha coefficient, suggesting high reliability (greater than 0.6 recommended by Nunally and Bernstein) and internal consistency. The results of Hotelling's Tsquared test confirmed that the mean of different apparel buying behaviour items under the five dimensions was significantly differ from each other at 1percent level. This shows that there is no equivalence between all the 25 items and that they are different. 
Table 2: Reliability Analysis

\begin{tabular}{|l|l|l|l|l|l|l|l|}
\hline Dimensions & $\begin{array}{l}\text { No. of } \\
\text { Items }\end{array}$ & $\begin{array}{l}\text { Cronbach's } \\
\text { Alpha }\end{array}$ & $\begin{array}{l}\text { Cronbach's } \\
\text { Alpha Based } \\
\text { on } \\
\text { Standardized } \\
\text { Items }\end{array}$ & $\begin{array}{l}\text { Hotelling's } \\
\text { T-Squared } \\
\text { Test }\end{array}$ & $\begin{array}{l}\text { F } \\
\text { value }\end{array}$ & Df & $\begin{array}{l}\text { p- } \\
\text { value }\end{array}$ \\
\hline Store Attributes & 5 & .879 & .882 & 191.60 & 47.61 & 4,496 & .000 \\
\hline $\begin{array}{l}\text { Product } \\
\text { Attributes }\end{array}$ & 5 & .928 & .929 & 425.21 & 31.11 & 4,496 & .000 \\
\hline $\begin{array}{l}\text { Reference } \\
\text { Groups }\end{array}$ & 5 & .875 & .826 & 79.46 & 19.74 & 4,496 & .000 \\
\hline $\begin{array}{l}\text { Consumer } \\
\text { characteristics }\end{array}$ & 5 & .925 & .925 & 380.69 & 44.90 & 4,496 & .000 \\
\hline $\begin{array}{l}\text { Promotional } \\
\text { Factors }\end{array}$ & 5 & .827 & .830 & 793.86 & 48.18 & 4,496 & .000 \\
\hline
\end{tabular}

\section{Basic Information: Branded apparels}

This section gives general information and views about the sample respondents on Brand Awareness and shopping habits.

\section{Brand Awareness and shopping habits}

Accessibility of branded apparels among Indians has transformed as in the past, very few consumers could afford them. The landscape of brand awareness in India is changing and people are very much aware of the brand culture prevalent in our country. Young Consumers, today are cognisant of most of the national and International brands. As shown in in Fig 1, (A), 97 percent of the respondents said that they buy branded apparels. Foreign companies seek to capture the attention of the young consumers through various promotional techniques and advertising. Consequently, Brands create awareness in the consumers mind even before they are available in the stores and once they are out in the market, consumers are geared up to search for these and purchase them.

Also the increase purchasing power of many urban Indians has led to more people being able to afford branded apparels. In fig 1, (B) it is exhibited that 35 percent of the respondents prefer to buy national brands and 40 percent of respondents prefer to buy a combination of both national and international brands. McKinsey conducted a proprietary research project on apparel-shopping attitudes and behaviour and concluded, that as consumers have greater disposable income, they increasingly spend their money on items beyond the basic necessities. One of the first categories to feel this change is apparel.

When respondents were asked that where they go for shopping for apparels, a major segment i.e. 68 percent as shown in Fig 1, (C) responded that they prefer malls over traditional shops and e-shopping. This is primarily on account of convenience offered to them in terms of assortment of wide variety of stocks in terms of styles, colour, price range, brands, sizes etc. which they can try before purchase all at one place. This trend highlights the mall mania amongst the youth and the craze for shopping there. Also the pleasure of shopping is enhanced with various recreational facilities like Cineplex's, eating joints, games zones like bowling etc. which makes them stay for long within the mall.

For Indian shoppers, Consumers' wardrobe is shifting from need- based clothing to occasion specific dressing and is gradually becoming more detail- oriented (Textile and apparel 
compendium 2012, Technopak).Most of the youngsters today buy apparels for special events or occasions. Occasion specific dressing and important festivals also many a times influences impulse buying amongst the youth. In a country like India, youngsters are mostly in festive mood due to various festival occasions round the year which acts as a powerful stimulant. The Indian consumer is clearly enjoying the modern trade shopping experience and is increasingly shopping there, as is evident from the increased spending at modern stores. Fig 1, (D), shows that 89 percent of the respondents buy clothing for special events or festivals.

Consumer's response to the frequency of purchasing branded apparel exhibited that most of them indulge in shopping for apparels occasionally. Fig 1, (E), exhibits, 60 percent of the respondents buying branded apparels occasionally. As discussed that the aspirations of purchasing apparels are constantly changing in the youth's mind, marketers must understand their shopping behaviour and make persistent marketing efforts to transmit the frequency of buying behaviour from occasionally to frequently. This could be done through various promotional offers which can act as a powerful stimulant for a consumer to visit the store and shop.

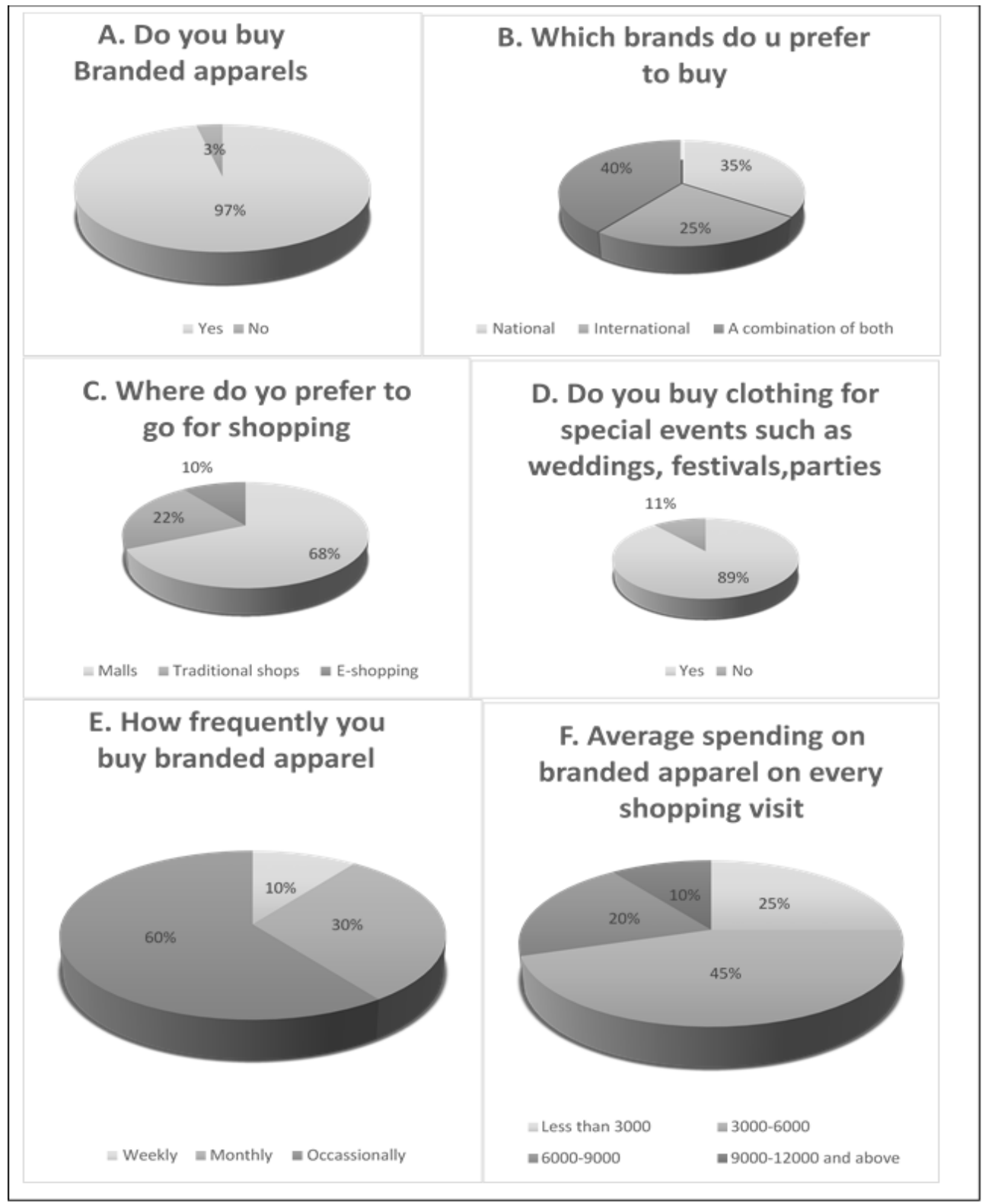

Fig 1: Brand Awareness and Shopping Habits 
Given the inflationary pressures on the household budget, Indian consumers have become all the more value conscious. The access to both modern and traditional trade formats coupled with an awareness of various deals being offered in the market, allows the consumer to make a more informed, value-for-money shopping decision. People in India are price sensitive and don't prefer spending more than 5000 rupees each time they go out for shopping. This gives a clear indication to marketer as majorly the Indian consumers are under Middle income group segment (as per the census 2011 report, The Indian middle class, target consumers for many companies, is expected to swell up to 267 million people in the next five years, up 67 per cent from the current levels) and on account of income constraint don't wish to spend beyond a limit. Marketers must embed this buying behaviour while formulating their strategies and come up with low range or eco range of products to encourage the consumers to buy which could eventually lead to an increase in the shopping expenditure. Fig 1, (F), below shows that 25 percent of respondents prefer less than 3000 rupees, 45 percent spend somewhere between rupees 3000-6000, 20 percent between 6000-9000 rupees while only 10 percent end up spending in the range of 9000-12000

\section{Buying behaviour dimensions: Gender Perspective}

For the analysis, the sample respondents have been classified on the basis of gender i.e. females and males. Statistical comparisons have been made between variables across males and females using a student sample $t$-test to establish if the means are statistically different. The hypothesis to be tested is:

$\mathrm{H}_{1}$ : Males and females carry out differences in their buying behaviour dimensions.

\section{Tests of Normality}

In order to conduct Independent Sample Student t-test, the data needs to meet the assumption of normality. The different dimensions of buying behavior across genders i.e. males and females were normally distributed, as assessed by Shapiro- wilks test ( $p>.05$ ) (Shapiro \& Wilk, 1965; Razali \& Wah ,2011). A Levene's test verified the equality of variances in the samples (homogeinity of variance)(p>.05) (Martin \& Bridgmon, 2012).

The independent samples t- test was used to find a difference between the means of two independent samples, which in this study refers to females and males with respect to the attributes applied while choosing branded apparel. The results are as follows:

\section{Store Attributes}

To make analysis, table presentations have been made. Table 5.4 shows the $t$-values of variables under store attributes of sample males and females. 
Table 3 Variables considered under store attributes of buying behaviour for males and females

\begin{tabular}{|c|c|c|c|c|c|c|c|c|c|c|}
\hline & \multirow{2}{*}{\multicolumn{2}{|c|}{$\begin{array}{l}\text { Levene's } \\
\text { Test for } \\
\text { Equality of } \\
\text { Variances } \\
\end{array}$}} & \multirow{2}{*}{\multicolumn{7}{|c|}{ t-test for Equality of Means }} \\
\hline & & & & & & & & & & \\
\hline & & \multirow[t]{2}{*}{$F$} & \multirow[t]{2}{*}{ Sig. } & \multirow[t]{2}{*}{$\mathrm{T}$} & \multirow[t]{2}{*}{ Df } & \multirow[t]{2}{*}{\begin{tabular}{|l|} 
Sig. \\
$(2-$ \\
tailed)
\end{tabular}} & \multirow[t]{2}{*}{$\begin{array}{l}\text { Mean } \\
\text { Difference }\end{array}$} & \multirow[t]{2}{*}{$\begin{array}{l}\text { Std. Error } \\
\text { Difference }\end{array}$} & \multicolumn{2}{|c|}{$\begin{array}{l}95 \% \\
\text { Confidence } \\
\text { Interval }\end{array}$} \\
\hline & & & & & & & & & Lower & Upper \\
\hline \multirow[t]{2}{*}{$\begin{array}{l}\text { Services of } \\
\text { staff }\end{array}$} & $\begin{array}{l}\text { Equal } \\
\text { variances } \\
\text { assumed }\end{array}$ & 1.417 & .234 & -.072 & 498 & .943 & -.006 & .086 & -.176 & .164 \\
\hline & $\begin{array}{l}\text { Equal } \\
\text { variances } \\
\text { not } \\
\text { assumed }\end{array}$ & & & -.073 & 387.071 & .942 & -.006 & .085 & -.173 & .160 \\
\hline \multirow[t]{2}{*}{$\begin{array}{l}\text { Membership } \\
\text { facility }\end{array}$} & $\begin{array}{l}\text { Equal } \\
\text { variances } \\
\text { assumed } \\
\end{array}$ & .418 & .518 & .164 & 498 & .870 & .015 & .094 & -.169 & .200 \\
\hline & $\begin{array}{l}\text { Equal } \\
\text { variances } \\
\text { not } \\
\text { assumed }\end{array}$ & & & .165 & 370.028 & .869 & .015 & .094 & -.169 & .200 \\
\hline \multirow[t]{2}{*}{$\begin{array}{l}\text { Physical } \\
\text { facility }\end{array}$} & $\begin{array}{l}\text { Equal } \\
\text { variances } \\
\text { assumed } \\
\end{array}$ & 1.259 & .262 & 3.12 & 498 & .044 & .009 & .085 & -.158 & .177 \\
\hline & $\begin{array}{l}\text { Equal } \\
\text { variances } \\
\text { not } \\
\text { assumed }\end{array}$ & & & 3.10 & 381.420 & .036 & .009 & .084 & -.156 & .175 \\
\hline \multirow[t]{2}{*}{$\begin{array}{l}\text { Post- } \\
\text { transaction } \\
\text { services }\end{array}$} & $\begin{array}{l}\text { Equal } \\
\text { variances } \\
\text { assumed }\end{array}$ & 2.486 & .116 & -1.046 & 498 & .296 & -.107 & .102 & -.307 & .094 \\
\hline & $\begin{array}{l}\text { Equal } \\
\text { variances } \\
\text { not } \\
\text { assumed }\end{array}$ & & & -1.069 & 390.037 & .286 & -.107 & .100 & -.303 & .089 \\
\hline \multirow[t]{2}{*}{ Variety } & $\begin{array}{l}\text { Equal } \\
\text { variances } \\
\text { assumed } \\
\end{array}$ & 4.209 & .141 & 2.02 & 498 & .024 & -.050 & .106 & -.259 & .158 \\
\hline & $\begin{array}{l}\text { Equal } \\
\text { variances } \\
\text { not } \\
\text { assumed }\end{array}$ & & & 2.08 & 396.706 & .029 & -.050 & .103 & -.253 & .153 \\
\hline
\end{tabular}

The results of the t-test presented in the above table, reveal that significant differences were found in the level of importance attributed by female and male respondents to the attributes of Physical facilities in a store and Variety. The independent sample t-test was associated with a statistically significant effect with $\mathrm{t}(498)=3.12, \mathrm{p}=.044$ for Physical facility and $\mathrm{t}(498)=2.02$, $\mathrm{p}=.024$ for Variety. Thus we may say that female consumers are more concerned about the physical facilities in a store in terms of spaciousness, adequate and convenient number of trial rooms to the customers with sufficient lighting and mirrors as is revealed by the survey where 70 percent of the female respondents responded that for them Physical facilities in a store are extremely important, whereas only 40 percent of their male counterparts favoured in favour of this variable. With respect to variety, 82 percent of females responded that it is important for them that the store they go to shop for apparel has wide assortment of stock so that it facilitates them to make an easier choice. For males on the contrary, only 53 percent strongly 
agreed in favour of this variable. This is supported by Chen-Yu and Seock (2002) who conducted a study to investigate the clothing purchase motivations, information sources and selection criteria of young male and female consumers, aged between 13 and 19. Their findings revealed that, "for both male and female participants, price was the most important store selection criterion" (Chen-Yu and Seock 2002). Furthermore, "female participants considered product variety/availability and store display significantly more important than male participants", while there were no significant differences between males and females in terms of perceptions of importance regarding the attributes of store environment/community involvement and customer service/store image, thus "assigning similar weights to the importance" of these factors (Chen-Yu and Seock 2002).

Dholakia (1999) concurs with Chen-Yu and Seock (2002) and also suggests that "the female patron will continue to be the main target of store layout and design efforts". In the study conducted by Chen-Yu and Seock (2002), the attribute of Product variety/availability included dimensions such as availability of different sizes, wide variety of different styles, and availability of well-known brands, while the attribute of store display also refers to factors such as window and product displays, and attractive store layout (Chen-Yu and Seock 2002). A possible explanation for the female participants regarding these attributes to be more important than the male participants may be due to the females shopping motivation of recreation, as "product variety and store display increase the fun and enjoyment" (Chen-Yu and Seock 2002).

Since females are more emotional in their appeal, the buying environment may play a more important role for women customers. They see shopping as a fun, joyful and hedonic activity and look forward to this communal event with cheerful prospects.

\section{Product Attributes}

To make analysis, table presentations have been made. Table 4 on next page shows the $t$-values of variables under product attributes of sample males and females.

The results of the t-test presented in the table below, reveal that significant differences were found in the level of importance attributed by female and male respondents to the attributes of Style of apparels. The independent sample t-test was associated with a statistically significant effect with $t(498)=2.01, p=.039$ for Style attribute. It is revealed by the survey that 81 percent of the female respondents responded that while buying apparel, it is of utmost importance that they should be stylish and suit to their personality, whereas only 56 percent of their male counterparts favoured in favour of this variable This is supported by Zhang et al. (2002) who concurs that, of all the demographic variables, "Gender is the one that has significant impacts on the importance of most of the attributes". Accordingly, it was found that the female Chinese consumers regarded the attributes of fit, comfort, style, colour and easy care to be more important compared to the male respondents with regard to choosing casual clothing, whereas there was no significant difference in the importance ratings of price, workmanship and trendiness between the two genders (Zhang et al. 2002). 
Table 4- Variables considered under product attributes of buying behaviour for males and females

\begin{tabular}{|c|c|c|c|c|c|c|c|c|c|c|}
\hline & \multicolumn{2}{|c|}{$\begin{array}{l}\text { Levene's Test } \\
\text { for Equality } \\
\text { of Variances }\end{array}$} & \multicolumn{7}{|c|}{ t-test for Equality of Means } \\
\hline & & \multirow[t]{2}{*}{$\mathrm{F}$} & \multirow[t]{2}{*}{ Sig. } & \multirow[t]{2}{*}{$\mathrm{T}$} & \multirow[t]{2}{*}{$\overline{d f}$} & \multirow[t]{2}{*}{$\begin{array}{l}\text { Sig. } \\
(2- \\
\text { tailed })\end{array}$} & \multirow[t]{2}{*}{$\begin{array}{l}\text { Mean } \\
\text { Difference }\end{array}$} & \multirow[t]{2}{*}{$\begin{array}{l}\text { Std. Error } \\
\text { Difference }\end{array}$} & \multicolumn{2}{|c|}{$\begin{array}{l}95 \% \text { Confidence } \\
\text { Interval of the } \\
\text { Difference }\end{array}$} \\
\hline & & & & & & & & & Lower & Upper \\
\hline \multirow[t]{2}{*}{ Fit } & $\begin{array}{l}\text { Equal } \\
\text { variances } \\
\text { assumed }\end{array}$ & 1.297 & .255 & -1.121 & 498 & .263 & -.111 & .099 & -.307 & .084 \\
\hline & $\begin{array}{l}\text { Equal } \\
\text { variances } \\
\text { not } \\
\text { assumed }\end{array}$ & & & -1.144 & 388.282 & .253 & -.111 & .097 & -.303 & .080 \\
\hline \multirow[t]{2}{*}{ Durability } & $\begin{array}{l}\text { Equal } \\
\text { variances } \\
\text { assumed }\end{array}$ & 2.299 & .130 & -.483 & 498 & .629 & -.044 & .092 & -.224 & .136 \\
\hline & $\begin{array}{l}\text { Equal } \\
\text { variances } \\
\text { not } \\
\text { assumed }\end{array}$ & & & -.495 & 392.658 & .621 & -.044 & .089 & -.220 & .131 \\
\hline \multirow[t]{2}{*}{ Style } & $\begin{array}{l}\text { Equal } \\
\text { variances } \\
\text { assumed }\end{array}$ & 1.465 & .227 & 2.01 & 498 & .039 & -.016 & .099 & -.210 & .177 \\
\hline & $\begin{array}{l}\text { Equal } \\
\text { variances } \\
\text { not } \\
\text { assumed }\end{array}$ & & & 2.05 & 380.261 & .031 & -.016 & .097 & -208 & .175 \\
\hline \multirow[t]{2}{*}{ Price } & $\begin{array}{l}\text { Equal } \\
\text { variances } \\
\text { assumed }\end{array}$ & .524 & .469 & -.982 & 498 & .327 & -.093 & .095 & -280 & .094 \\
\hline & $\begin{array}{l}\text { Equal } \\
\text { variances } \\
\text { not } \\
\text { assumed }\end{array}$ & & & -.992 & 376.329 & .322 & -.093 & .094 & -.279 & .092 \\
\hline \multirow[t]{2}{*}{ Quantity } & $\begin{array}{l}\text { Equal } \\
\text { variances } \\
\text { assumed }\end{array}$ & 2.038 & .154 & -1.139 & 498 & .255 & -.118 & .103 & -.321 & .085 \\
\hline & $\begin{array}{l}\text { Equal } \\
\text { variances } \\
\text { not } \\
\text { assumed }\end{array}$ & & & -1.149 & 374.582 & .251 & -.118 & .103 & -.320 & .084 \\
\hline
\end{tabular}

Style is a form of Self Expression that help the youngsters to cope with social situations. The right style provides them with acceptance and identity among peers and makes them feel trendy. According to (Cox and Dittmar 1995 cited in Bakewell et al. 2006), female students perceive clothes "in terms of their symbolic value for gaining approval and acceptance from peers"

\section{Reference Groups}

To make analysis, table presentations have been made. Table 5 shows the $t$-values of variables under reference groups of sample males and females. 
Table 5 -Variables considered under reference group of buying behaviour for males and females

\begin{tabular}{|c|c|c|c|c|c|c|c|c|c|c|}
\hline & \multicolumn{2}{|c|}{$\begin{array}{l}\text { Levene's } \\
\text { Test for } \\
\text { Equality of } \\
\text { Variances } \\
\end{array}$} & \multicolumn{7}{|c|}{ t-test for Equality of Means } \\
\hline & & \multirow[t]{2}{*}{$\mathrm{F}$} & \multirow[t]{2}{*}{ Sig. } & \multirow[t]{2}{*}{$\mathrm{t}$} & \multirow[t]{2}{*}{ Df } & \multirow[t]{2}{*}{$\begin{array}{l}\text { Sig. } \\
(2- \\
\text { tailed })\end{array}$} & \multirow[t]{2}{*}{$\begin{array}{l}\text { Mean } \\
\text { Difference }\end{array}$} & \multirow[t]{2}{*}{$\begin{array}{l}\text { Std. Error } \\
\text { Difference }\end{array}$} & \multicolumn{2}{|c|}{$\begin{array}{l}95 \% \\
\text { Confidence } \\
\text { Interval of the } \\
\text { Difference }\end{array}$} \\
\hline & & & & & & & & & Lower & Upper \\
\hline \multirow[t]{2}{*}{$\begin{array}{ll}\text { Influence } & \text { of } \\
\text { family } & \text { of } \\
\text { friends } & \end{array}$} & $\begin{array}{l}\text { Equal } \\
\text { variances } \\
\text { assumed }\end{array}$ & .004 & .949 & 2.12 & 498 & .031 & -.017 & .110 & -.234 & .199 \\
\hline & $\begin{array}{l}\text { Equal } \\
\text { variances } \\
\text { not } \\
\text { assumed }\end{array}$ & & & 2.17 & 363.118 & .029 & -.017 & .110 & -.235 & .200 \\
\hline \multirow[t]{2}{*}{$\begin{array}{l}\text { Celebrity } \\
\text { Influence }\end{array}$} & $\begin{array}{l}\text { Equal } \\
\text { variances } \\
\text { assumed }\end{array}$ & 3.225 & .073 & -1.215 & 498 & .225 & -.128 & .105 & -.334 & .079 \\
\hline & $\begin{array}{l}\text { Equal } \\
\text { variances } \\
\text { not } \\
\text { assumed }\end{array}$ & & & -1.200 & 352.253 & .231 & -.128 & .106 & -.337 & .082 \\
\hline \multirow[t]{2}{*}{$\begin{array}{l}\text { Past } \\
\text { Experience }\end{array}$} & $\begin{array}{l}\text { Equal } \\
\text { variances } \\
\text { assumed }\end{array}$ & 1.513 & .219 & -.266 & 498 & .790 & -.025 & .096 & -.214 & .163 \\
\hline & $\begin{array}{l}\text { Equal } \\
\text { variances } \\
\text { not } \\
\text { assumed }\end{array}$ & & & -.271 & 384.160 & .787 & -.025 & .094 & -.210 & .160 \\
\hline \multirow[t]{2}{*}{ TV/Magazine } & $\begin{array}{l}\text { Equal } \\
\text { variances } \\
\text { assumed }\end{array}$ & .676 & .411 & -.805 & 498 & .421 & -.092 & .114 & -.317 & .133 \\
\hline & $\begin{array}{l}\text { Equal } \\
\text { variances } \\
\text { not } \\
\text { assumed } \\
\end{array}$ & & & -.812 & 374.013 & .417 & -.092 & .113 & -.315 & .131 \\
\hline \multirow[t]{2}{*}{ Internet } & $\begin{array}{l}\text { Equal } \\
\text { variances } \\
\text { assumed }\end{array}$ & .917 & .339 & -.871 & 498 & .384 & -.098 & .113 & -.320 & .123 \\
\hline & $\begin{array}{l}\text { Equal } \\
\text { variances } \\
\text { not } \\
\text { assumed }\end{array}$ & & & -.885 & 381.920 & .377 & -.098 & .111 & -.317 & .120 \\
\hline
\end{tabular}

The results of the t-test presented in the above table, reveal that significant differences were found in the level of importance attributed by female and male respondents to the attributes of Influence of family and friends. The independent sample t-test was associated with a statistically significant effect with $t(498)=2.12, p=.031$. The survey results revealed that 63 percent of females strongly agree that family and friends hold a strong opinion for them while they are shopping for apparels. For males, 51 percent strongly agreed regarding the importance of this variable. As stated earlier, female students perceive clothes "in terms of their symbolic value for gaining approval and acceptance from peers" (Cox and Dittmar 1995 cited in Bakewell et al. 2006). Zhang et al. (2002). It has been suggested that individuals are more susceptible to reference group influence when the product is conspicuous and publicly 
consumed (Bearden and Etzel, 1982; Makgosa and Mohube, 2007) such as fashion apparel and accessories. Females place greater value on promoting and maintaining relationships. They are highly conscious and concerned with promoting interpersonal harmony (Rosenberg and Simmons, 1975). Females tend to discuss consumption matters with peers, such as information search, purchase decisions and brand preferences more frequently than males (Mangleburg et al. 1997; Moschis and Mitchell 1986). Differences have also been observed with respect to parental influence. For instance, females have in the past demonstrated a higher degree of parental influence as compared to males (Feltham, 1998). In addition, gender differences have also been observed with respect to friends, siblings and media influence (Wilson and MacGillivray, 1998). Feltham (1998) also reported that females have demonstrated a higher degree of parental influence as compared to males. The findings are contradictory to the study conducted by (Bearden and Etzel, 1982; Makgosa and Mohube, 2007) who suggested that males, rather than females, are more likely to purchase designer label brands to be accepted by their friends.

\section{Consumer Characteristics}

To make analysis, table presentations have been made. Table 6 shows the $t$-values of variables under consumer characteristics of sample males and females.

The results of the t-test presented in the table below, reveal that significant differences were found in the level of importance attributed by female and male respondents to the attributes of Preference to wear and try before purchase, Store image and Brand Loyalty. The independent sample t-test was associated with a statistically significant effect with $t$ (498) $=2.13, \mathrm{p}=.014$ for Preference to wear and try before purchase, $\mathrm{t}(498)=2.15, \mathrm{p}=.035$ for Store Image and $t(498)=2.16, p=.023$ for Brand loyalty. Survey results revealed that 68 percent females prefer to wear and try the product before purchasing it while in case of males this figure stood at 54 percent. For store image, 73 percent females strongly agreed that store image is important for them and 69 percent of them said they tend to visit the same shop for buying a particular brand and hence are more store loyal and brand loyal as compared to their male counterparts with a huge difference as only 44 percent of males agreed that store image is important to them while 38 percent tend to be brand loyal customers. Lysonksi et al. (1996) indicated that the consumer characteristics approach seemed to be the most powerful and explanatory as it focused on the mental orientation of consumers in making decisions. This is in coherence with previous studies. With regard to the specific shopping behaviour and preferences of males and females, "women want choice, and they're willing to try on way more articles of clothing than men are to find the right thing" (Yarrow and O'Donnell 2009), while "men, on the other hand, view lots of choice as overwhelming" (Yarrow and O'Donnell 2009). Accordingly, women "may be more apt to bargain-hunt when it comes to fashion" (Smith 2008), while men are "more focused on solutions than on options" (Yarrow and 0'Donnell 2009). Furthermore, according to Mulpuru, a Research Analyst, "men tend to value their time more" (Smith 2008) and are thus "much more forthright than women in expecting quick checkout service" (Yarrow and O’Donnell 2009). Men do not, however, "like to ask for advice, insight, or different sizes" (Yarrow and O'Donnell 2009). With regard to online shopping in particular, men have been described as a "retailer's dream" as they "spend more, make snap decisions, and return less stuff" (Smith 2008). Ultimately, men and women use fashion in different ways: "women tend to enjoy fashion in its own right, as creative expression and as a social vehicle", while "men use fashion and dressing in a solution-focused way" (Yarrow and O’Donnell 2009). 
Table 6- Variables considered under consumer characteristics of buying behaviour for males and females

\begin{tabular}{|c|c|c|c|c|c|c|c|c|c|c|}
\hline & \multicolumn{2}{|c|}{$\begin{array}{l}\text { Levene's } \\
\text { Test for } \\
\text { Equality of } \\
\text { Variances }\end{array}$} & \multicolumn{7}{|c|}{ t-test for Equality of Means } \\
\hline & & \multirow[t]{2}{*}{$\mathrm{F}$} & \multirow[t]{2}{*}{ Sig. } & \multirow[t]{2}{*}{$\mathrm{T}$} & \multirow[t]{2}{*}{$\mathrm{df}$} & \multirow[t]{2}{*}{$\begin{array}{l}\text { Sig. } \\
\text { (2- } \\
\text { tailed) }\end{array}$} & \multirow[t]{2}{*}{$\begin{array}{l}\text { Mean } \\
\text { Difference }\end{array}$} & \multirow[t]{2}{*}{$\begin{array}{l}\text { Std. Error } \\
\text { Difference }\end{array}$} & \multicolumn{2}{|c|}{$\begin{array}{l}95 \% \\
\text { Confidence } \\
\text { Interval of the } \\
\text { Difference }\end{array}$} \\
\hline & & & & & & & & & Lower & Upper \\
\hline \multirow{2}{*}{$\begin{array}{l}\text { Preference to } \\
\text { wear and try } \\
\text { before } \\
\text { purchase }\end{array}$} & $\begin{array}{l}\text { Equal } \\
\text { variances } \\
\text { assumed }\end{array}$ & .000 & .989 & 2.13 & 498 & .014 & -.068 & .114 & -.293 & .157 \\
\hline & $\begin{array}{l}\text { Equal } \\
\text { variances } \\
\text { not } \\
\text { assumed }\end{array}$ & & & 2.16 & 365.775 & .021 & -.068 & .114 & -.293 & .157 \\
\hline \multirow[t]{2}{*}{$\begin{array}{l}\text { Fashion } \\
\text { Consciousness }\end{array}$} & $\begin{array}{l}\text { Equal } \\
\text { variances } \\
\text { assumed }\end{array}$ & .009 & .924 & -1.057 & 498 & .291 & -.122 & .116 & -.350 & . 105 \\
\hline & $\begin{array}{l}\text { Equal } \\
\text { variances } \\
\text { not } \\
\text { assumed }\end{array}$ & & & -1.050 & 358.055 & .294 & -.122 & .117 & -.351 & .107 \\
\hline \multirow[t]{2}{*}{$\begin{array}{l}\text { Impulse } \\
\text { buying } \\
\text { behavior }\end{array}$} & $\begin{array}{l}\text { Equal } \\
\text { variances } \\
\text { assumed }\end{array}$ & .822 & .365 & -.836 & 498 & .403 & -.101 & .121 & -.340 & .137 \\
\hline & $\begin{array}{l}\text { Equal } \\
\text { variances } \\
\text { not } \\
\text { assumed }\end{array}$ & & & -.844 & 374.780 & .399 & -.101 & .120 & -.338 & .135 \\
\hline \multirow[t]{2}{*}{ Store Image } & $\begin{array}{l}\text { Equal } \\
\text { variances } \\
\text { assumed }\end{array}$ & .000 & .986 & 2.15 & 498 & .035 & -.104 & .108 & -.316 & .108 \\
\hline & $\begin{array}{l}\text { Equal } \\
\text { variances } \\
\text { not } \\
\text { assumed }\end{array}$ & & & 2.11 & 377.686 & .033 & -.104 & .107 & -.314 & .106 \\
\hline \multirow[t]{2}{*}{ Brand loyalty } & $\begin{array}{l}\text { Equal } \\
\text { variances } \\
\text { assumed }\end{array}$ & .360 & .549 & 2.16 & 498 & .023 & -.007 & .113 & -.229 & .214 \\
\hline & $\begin{array}{l}\text { Equal } \\
\text { variances } \\
\text { not } \\
\text { assumed }\end{array}$ & & & 2.09 & 357.367 & .031 & -.007 & .113 & -.230 & .216 \\
\hline
\end{tabular}

With regard to gender differences in terms of attribute salience, "men give more prominence to proximity. Women tend to trade this off with merchandise offered by the store" (Sinha et al. 2002). This may be due to the fact that women often "buy for other members of the family and hence would like to make a more informed decision" (Sinha et al. 2002)

Bakewell and Mitchell (2006) conducted a study investigating the decision making styles of males versus female consumers. Female shoppers in the study tended to be bargain seekers, where they purchase as much as possible at sale prices; demonstrate the "imperfectionism" trait, where they will settle for a product which is not precisely what they require nor the best 
in its category; as well as being store loyal, where they tend to visit the same stores each time they shop (Bakewell and Mitchell 2006).

\section{Promotional Factors}

To make analysis, table presentations have been made. Table 7 shows the $t$-values of variables under promotional factors of sample males and females.

Table 7- Variables considered under promotional factors of buying behaviour for males and females

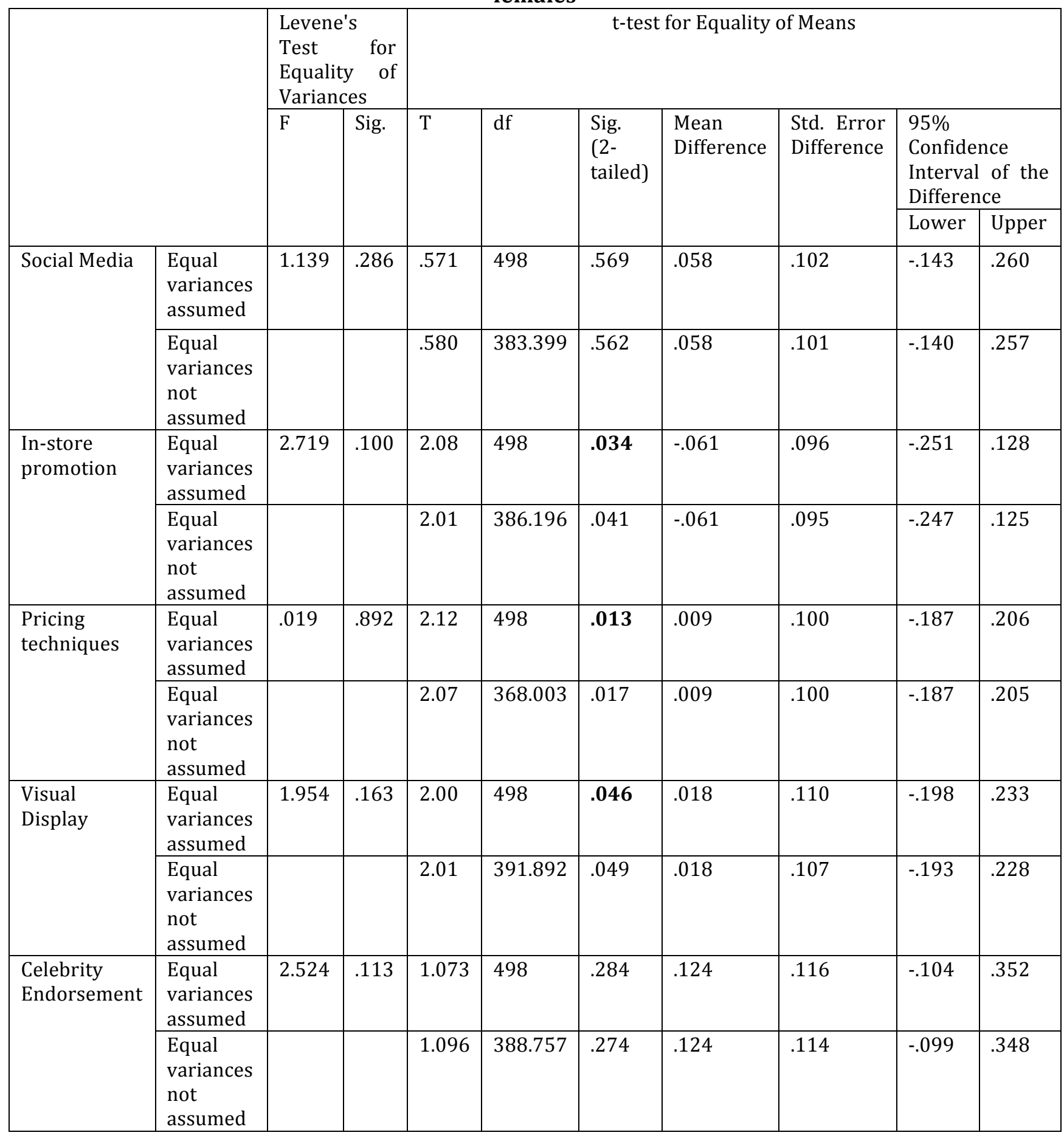

The results of the t-test presented in the above table, reveal that significant differences were found in the level of importance attributed by female and male respondents to the attributes of In-store promotions, Pricing techniques and visual displays. The independent sample t- 
test was associated with a statistically significant effect with $\mathrm{t}(498)=2.08, \mathrm{p}=.034$ for in-store promotions, $\mathrm{t}(498)=2.12$, $\mathrm{p}=.013$ for Pricing techniques and $\mathrm{t}(498)=2.00, \mathrm{p}=.046$ for Visual displays According to the survey 73 percent, 62 percent and 60 percent of female respondents strongly agreed with respect to In-store promotions, pricing techniques and visual displays influencing their buying intentions. However these figures were significantly low for males, as only 43 percent, 54 percent and 33 percent of them tend to be strongly influenced by in-store promotions, pricing techniques and visual displays respectively.

Female consumers tend to be more influenced by various promotional techniques such as discounts, coupons, etc. when making decisions relating to apparel brands as they are more concerned with self-expression and gaining social approval as compared to males who are more rational in their approach.

Visual displays act as a powerful stimulant for a female shopper and drives them to enter a store as compared to male shoppers who don't as such bother about the outside appearance of a store. This is supported by previous studies which state that females have been found to be more sensitive to the informative details provided in advertisements (Auty and Elliot, 1998), or in the way information is processed (Laroche et al, 2000). With particular reference to susceptibility to interpersonal influence, females have been found to be more susceptible to the display aspects of clothing i.e. value-expressive influence, whereas males were more influenced by utilitarian aspects of the same (Rose, Boush and Friestad, 1998).

\section{Shopping Expenditure and shopping frequency between males and females}

In order to identify the dynamics of male and female buying behaviour with respect to Shopping Expenditure and shopping frequency , one - way ANOVA test has been used.

This technique is used to compare means of two or more samples.

\section{Shopping Expenditure}

To examine the male and female buying behaviour with respect to shopping expenditure, the following hypothesis has been tested using ANOVA.

\section{$\mathrm{H}_{2}$ : Males and females carry out differences in their shopping expenditure}

In order to apply one -way ANOVA test, the assumptions were duly met as data was normally distributed. The Shapiro- wilk test (p>.05) showed that shopping expenditure were approximately normally distributed for both males and females. Also Levene's test (homogeneity of variance) ( $\mathrm{p}>.05)$ (Martin \& Bridgmon, 2012) verified the equality of variances in the samples. In Table 8 below, the results of ANOVA shopping expenditure are shown.

Table 8 ANOVA Shopping Expenditure

\begin{tabular}{|l|c|c|c|c|c|}
\hline & $\begin{array}{c}\text { Sum of } \\
\text { Squares }\end{array}$ & Df & Mean Square & F & Sig. \\
\hline $\begin{array}{l}\text { Between } \\
\text { Groups }\end{array}$ & 1.792 & 1 & 1.792 & 7.96 & .022 \\
$\begin{array}{l}\text { Within } \\
\text { Groups } \\
\text { Total }\end{array}$ & 112.05 & 498 & .225 & & \\
\hline
\end{tabular}


As is exhibited from the above table, there is no statistically significant difference between groups as determined by one-way $\operatorname{ANOVA}(F(1,498)=7.96, p=.022)$. Thus the $\mathrm{H}_{2}$ is rejected i.e. Males and females carry out differences in their shopping expenditure and null hypothesis is accepted. Thus we may say that males and females in the age group of 18-25 years exhibit similar behavioural pattern when it comes to spending money for apparels and there are no significant differences between the two groups. As an emerging and growing market, the youth has been of interest in recent time's .Having a general liking for purchasing, this cohort has significant spending power and is likely to spend impulsively given the amount of free time they have for shopping (Der Hovanesian, 1999; Gardyn, 2002; Ma and Niehm, 2006). The Indian consumers today are becoming more materialistic. The Indian consumers need global, branded and local products. (Khanna and Palepu, 2006). The growth of Information technology, rapid changing fashion trends have made today's youth extremely fashion savvy and Brand conscious. Generation Y research conducted by Yarrow and O'Donnell (2009) show that men spend far less on shopping than their female counterparts. However, with changing times, it is evident that men of Generation $\mathrm{Y}$ are spending more on shopping for apparels as compared to men of previous generations. This is also because today men are equally conscious of their looks and appearance as women.

\section{Shopping Frequency}

To examine the male and female buying behaviour with respect to shopping expenditure, the following hypothesis has been tested using ANOVA.

\section{$\mathrm{H}_{3}$ : Males and females carry out differences in their shopping frequency}

In order to apply one -way ANOVA test, the assumptions were duly met as data was normally distributed. The Shapiro- wilk test ( $p>.05)$ showed that shopping frequency respectively were approximately normally distributed for both males and females. Also Levene's test (homogeneity of variance) ( $p>.05)$ (Martin \& Bridgmon, 2012) verified the equality of variances in the samples. In Table 9 below, the results of ANOVA shopping frequency are shown.

Table 9 ANOVA Shopping Frequency

\begin{tabular}{|l|c|c|c|c|c|}
\hline & $\begin{array}{c}\text { Sum of } \\
\text { Squares }\end{array}$ & df & Mean Square & F & Sig. \\
\hline $\begin{array}{l}\text { Between } \\
\text { Groups }\end{array}$ & 2.242 & 1 & 2.242 & 9.46 & .001 \\
$\begin{array}{l}\text { Within } \\
\text { Groups } \\
\text { Total }\end{array}$ & 118.23 & 498 & .237 & & \\
\hline
\end{tabular}

As exhibited from the above table there is no statistically significant difference between groups as determined by one-way ANOVA $(F(1,498)=9.46, p=.001)$ Thus the $\mathrm{H}_{3}$ is rejected i.e. Males and females carry out differences in their shopping frequency and null hypothesis is accepted. Thus we may say that males and females in the age group of 18-25 years exhibit similar behavioural pattern when it comes to shopping frequency for apparels and there are no significant differences between the two groups. Males and females today have an equal level of exposure with respect to every little aspects of life. Be it education, career, work-life, extra curricular activities etc. women are increasingly focussed and goal- oriented. Both the genders extensively make use of the information and communication technology and don't hold any gender differences attributable to shopping frequency. Males do not consider shopping as a 
feminine activity and are increasingly eager to shop for apparels as much as their counterparts. Otnes and McGrath (2001) conducted a study investigating the perceptions and realities of male shopping behaviour in which the findings contradicted the general male shopping stereotypes of "Grab and Go", "Whine and Wait" and "Fear of the Feminine". Accordingly, it was concluded that "men often evaluate alternatives, bargain, and even shop in "feminine stores" (Otnes and McGrath 2001). There are many reasons for this, such as the changing perceptions of shopping which is now seen as something "fun and sociable" (Yarrow and 0' Donnell 2009) and a way of spending time with friends; men have "gotten more particular in their tastes; and retailers have gotten better catering to them" (Yarrow and 0' Donnell 2009). Inevitably, gender differences are slowly fading as a "shift towards gender convergence" becomes more prominent (Yarrow and 0' Donnell 2009) and generally, "there's much more freedom for men to explore formerly female categories like cooking and clothes, and for women to dip traditionally guy categories like extreme sports and yard care" (Yarrow and O' Donnell 2009).A study analyzed the significance of demographic profile of consumers affecting the purchase decision of branded garments and to observe from gender perspective the consumer awareness about apparel brands available in the Indian market and also to find out whether there is a significant difference in total expenditure on branded apparels done by males vis- a vis females. The results reveal that there are no significant differences in the brand awareness, shopping frequency and shopping expenditure between males and females (Rajput, Kesharwani, Khanna, 2012).

Nevertheless, retailers must still note that the main "interests" of both men and women have remained almost unchanged, with men spending " big on luxury" (Smith 2008), as well as preferring to purchase "music, electronics, games and sporting equipment", while women prefer to shop for " clothing, accessories and home decorations" (Yarrow and 0' Donnell 2009)

\section{DISCUSSIONS AND IMPLICATIONS}

A) The study indicates that Consumers are aware of most of the national and International brands available in the country and have immense craze for shopping in malls. This has a very important implication for the marketer as they must take effective steps to ensure that they create an entertaining shopping environment cognisant of the fact that the longer the shoppers' stay in a store and more goods they are exposed to. So providing various enhancements to shopping experience in terms of amenities like cafes, various forms of entertainment etc. might increase the sales volume.

B) Given the erratic and ever-changing mind- set of the young consumers, marketers must understand their shopping behaviour and make persistent marketing efforts to transmit the frequency of buying behaviour from occasionally to frequently. This could be done through various promotional offers which can act as a powerful stimulant for a consumer to visit the store and shop. Indian consumers today have become all the more value conscious and given their budgetary constraints, it's extremely important for the marketer, to come up with low range/ eco- range of products to cater to a larger segment.

C) Taking the gender perspective into consideration, it was revealed that female respondents place greater importance to attributes such as Physical facilities, Variety, Style, Family and friends, store image, Brand Loyalty, Preference to wear and try before purchase, and promotional factors as compared to their male counterparts. Female shoppers tend to be bargain seekers when it comes to apparels and their purchase decisions are significantly influenced by discount schemes. Thus marketers must embed this in their strategies by 
coming up with appealing advertising, convenient locations, low prices for their female shoppers.

D) The study reveals similar behavioural patterns between males and females with respect to shopping expenditure and shopping frequency. This has a very important implication for the marketer as they must understand that men of today are equally conscious of their looks, appearance and style as are females. Hence it is imperative that a wide range of products in terms of variety, latest trends, colours etc. be available for this gender as well. Gone are the days when colour pink was only associated with females. The male gender today has equally become experimental and prefer variety of vibrant colours as do their female counterparts.

E) This study contributes to academia by providing a conceptual framework to understand apparel buying behaviour of young India consumers. Practitioners may also utilize this model in the present study to improve their retailing strategies to increase their retail sales by offering well-maintained retail services, facilities, promotions and quality merchandise. The marketers must play a decisive role to understand the Consumer buying behaviour for branded apparels and cater to this younger segment more profitably.

F) Marketers need to put in their best efforts to deeply understand the consumer behaviour rather than just concentrating on ambience and sheer novelty to increase sales. With fast changing trends in fashion cycles, it is imperative for the marketer to be dynamic and flexible in their approach for a better understanding of consumer behaviour. This will lead to a reduction in failure rate. Marketer must do away with unnecessary increase in overhead expenses and offer variety of products at cheaper prices. They must come up with good business models and have a whole new orientation to meet customer demands. The study represents the young consumers in the age group of 18-25years also called a 'Twixter'. For this group, marketers should focus on and emphasize the attributes that have been considered to be the most influential in buying decisions. The key to win their confidence and retain them is to understand deeply their needs and to deliver more value than the rivals.

\section{LIMITATIONS AND SUGGESTIONS FOR FUTURE RESEARCH}

The study is only limited to Delhi/ NCR, Bangalore and Chandigarh region and hence findings cannot be generalized universally. The study investigates the buying behaviour for the apparel segment only. Future studies may examine buying behaviour in other retail segments. Also, the current study focusses on apparel buying behaviour in a retail store. Future studies can examine online apparel buying behaviour or buying through other retail formats. The present study is based on the consumer buying behaviour of branded apparels of only 500 respondents. Hence the sample may not be the true pointer of the entire universe and a larger sample size may be considered for future research. The present research has not considered age groups beyond 18-25 years. Hence the representative sample chosen for the study can be expanded to include consumer groups such as middle - aged or elderly groups to get a more comprehensive insight of consumer buying behaviour. Also, a future study on apparel buying behaviour of female consumers per se can be examined in a country like India as several literature revealed this segment to be highly lucrative and potentially profitable as they are the chief purchasing officers and decision makers in majority of households. 


\section{References}

Amit. G., Pakhie. S., Peush. N., Prakash. B., Ruby. J., Brahma.K.P. (2012). “Textile \& Apparel Compendium 2012”, www.technopak.com.

Auty, Elliott. (1998). Fashion involvement, self-monitoring and the meaning of brands. Journal of Product \&Brand Management, 7(2), 109-123. http://dx.doi.org/10.1108/10610429810216874

Bakewell, C. and Mitchell, V.W., (2006). Male versus female consumer decision making styles. Journal of Business Research, 59. pp. 1297-1300. Available:

http://www.sciencedirect.com/science?_ob=MImg\&_cid=271680\&_user=2822922\&_pii=S0148296306001317\&_ coverDate=11\%2F30\%2F2006\&view=c\&wchp=dGLzVlVzSkzV\&_valck=1\&md5=5adbe189a648fb68bcfc5a930fcd 9770\&ie=/sdarticle.pdf

Bearden, W.O., \& Etzel, M.(1982), “Reference Group Influence on Product and Brand Purchase Decisions”, Journal of Consumer Research, 9(2), 183-194

Berner, R., Khermouch, G. and Pascual, A. (2001), "Retail reckoning”, BusinessWeek Online, available at: www.businessweek.com/magazine/content/01_50/b3761089.htm

Chen-Yu, J.H and Seock, Y. (2002). Adolescents" Clothing Purchase Motivations. Information Sources, and Store Selection Criteria: A Comparison of Male/Female and Impulse/Nonimpulse Shoppers. Family and Consumer Sciences Research Journal, 31 (1).pp.50-77.Available: http://onlinelibrary.wiley.com/doi/10.1177/1077727X02031001003/pdf

Darden, W.R., \& Howell, R.D., (1987). Socialization effects of retail work experience on shopping orientations. Journal of the Academy of Marketing Science 15(3):52-63.

Davis, S.M. (1984). Managing corporate culture. Cambridge, Mass.: Ballinger.

Der Hovanesian, M., (1999) spending it, investing it - coming on strong: The children of the baby boomers are affecting spending and investing as their parents did; the similarity ends there. Wall Street Journal, Eastern Edition, p 12.

Dholakia, R.R., (1999), Going shopping: key determinants of shopping behaviours and motivations. International Journal of Retail and Distribution Management, 27 (4). pp.154-165.Available:

http://www.emeraldinsight.com/journals.htm?articleid=857255\&show=abstract

Dickson, A.M., Lennon, J.S., Montalto, C.P., Shen, D. and Zhang, L. (2004), “Chinese consumer market segments for foreign apparel products", Journal of Consumer Marketing, Vol. 21, pp. 301-317

Duncan, T. (2005). Principles of Advertising \& IMC, 2nd ed. New York, USA: McGraw-Hill Irwin

Eadie, D., Hastings, G., Stead, M. and Mackintosh, A.M. (1999). Branding: could it hold the key to future tobacco reduction policy? Health education, 99(3): 103-110.

Feltham, T.S.(1998), “Leaving Home: Brand Purchase Influences on Young Adults”, Journal of Consumer Marketing, 15(4), 372-385

Gardyn, R., (2002) Educated consumers. American Demographics 24 (10), 18-19.

Grossman, L., (2005). Grow Up? Not so Fast. Time, 24 January, pp. 1-6. Available: http://cseweb.ucsd.edu/ datorres/docs/grow_up_not_so_fast.pdf

Gurunathan,K.B., Krishnakumar, M.2013.” Factors Influencing Apparel Buying Behaviour in India: A Measurement Model "Paripex - Indian journal of research, Volume : 2, Issue : 3, March 2013

Hawkins, D.I., Mothersbaugh, D.L. and Best, R.J. (2007). Consumer Behaviour: Building Marketing Strategy. 10th ed. Boston: McGraw-Hill Irwin

Hu, T., Chuang, S., Hsieh, W., Chang, C. and Chang, C. (n.d). Investigating brand strategy, brand equity, and channel strategy on market performance - an empirical investigation of the cosmetic industry. Available: http://academicpapers.org/ocs2/session/ Papers/ G4/551-1867-1-DR.doc.

Kaiser, S. B. (1985). The social psychology of clothing and personal adornment. NewYork: Macmillan. 
Khanna, T., \& Palepu, K. G. (2006). Emerging giants: Building world class companies in developing countries. Harvard Business Review, 84(10), 60-69.

Kwan. C.Y, Yeung. K.W, Au. K.F (2004), "Decision - making Behaviour towards Casual Wear Buying: A Study of Young Consumers in Mainland China”, Journal of Management and World Business Research, Vol 1, No.1.

Laroche, M., Saad, G., Cleveland, M., \& Browne, E. (2000). Gender differences in information search strategies for a Christmas gift. Journal of Consumer Marketing, 17(6), 500-524.

Liu, T. and Wang, C. (2008), Factors affecting attitudes toward private labels and promoted brands, Journal of Marketing Management, 24(3), 283-298

Lysonski, S., Durvasula, S., \& Zotos, Y (1996), Consumer decision making styles: A multi country investigation. European Journal of Marketing, 30(12), 10-21. http://dx.doi.org/10.1108/03090569610153273

Ma, Y.J., Niehm, L.S., (2006). Service expectations of older generation Y customers: An examination of apparel retail settings. Managing Service Quality $16(6), 620-640$

Makgosa, R. \& Mohube, K.(2007), "Peer influence on young adults" product purchase decisions", African Journal of Business Management, June, pp.064-071

Mangelburg, T. F., Grewal, D. \& Bristol, T. (1997), "Socialization, gender, and adolescents" self-reports of their generalized use of product labels", Journal of Consumer Affairs, Vol. 31, 255-279

Martin, C.A. and Turley, L.W., (2004). Malls and Consumption motivation: an exploratory examination of older Generation Y consumers. International Journal of Retail and Distribution Management,32(10).pp.464475.Available: http://proquest.umi.com/pqdweb?did=725772301\&Fmt $=4 \&$ clientld $=30060 \& R Q T=309 \& V$ Name $=P Q D$

Martin, W.E., \& Bridgmon, K.D., (2012). Quantitative and statistical Research Methods: From Hypothesis to results. Somerset, NJ:Wiley

McCracken, G. (1988). The long interview. Newbury Park, CA: Sage Publications.

Moschis \& Mitchell (1986), “ Television advertising and interpersonal influences on teenagers' participation in family consumer decisions”, Advances in Consumer Research, Vol. 13, ed. Richard Lutz, Provo, UT: Association for Consumer Research, p. 181-186

Nunally, J.C., \& Bernstein, I. H. (1994). Psychometric theory (3rd ed.). New York: Mc Graw Hill

Otnes, C. and McGrath, M.A. (2001), Perceptions and realities of male shopping behaviour. Journal of Retailing,77.pp111-137. Available:http://www.sciencedirect.com/science?_ob=MImg\&_imagekey=B6W5D42SGGVW-7-

4\&_cdi=6568\&_user=2822922\&_pii=S0022435900000476\&_origin=gateway\&_coverDate $=01 \% 2 \mathrm{~F} 01 \% 2 \mathrm{~F} 2001 \&$ _S k=999229998\&view=c\&wchp=dGLzVtzzSkzS\&md5=30fff2ff613bdf7e70d2f31811fa5bf0\&ie=/sdarticle.pdf

Postrel, V. (2003), The Substance of Style: How the Rise of Aesthetic Value Is Remaking Commerce, Culture, and Consciousness, Harper Collins, New York.

Rajput, N., Kesharwani, S., Khanna, A. (2012). Consumer attitude towards branded Apparel: gender perspective. International Journal of Marketing Studies, Vol. 4(2).pp 111-120. http://dx.doi.org/10.5539/ijms.v4n2p111.

Razali, N.M., \& Wah, Y.B., (2011). Power comparisons of Shapiro -Wilk, Kolmogorov-Smirnov. Lilliefors and Anderson -darling tests. Journal of statistical Modelling and Analytics, 2(1), 21-33

Roach-Higgins, M.E., \& Eicher, J. B. (1992). Dress and identity. Clothing and Textiles Research Journal, 10(4), 1-8.

Rose, G.M., Boush, D.M. \& Friestad, M. (1998), "Self-esteem, susceptibility to interpersonal influence,and fashion attribute preferences in early adolescents," European Advances in Consumer Research, 3, 197-203

Russell-Bennett, R., McColl-Kennedy, J.R. and Coote, L.V. (2007). Involvement, satisfaction, and brand loyalty in a small business services setting, Journal of Business Research 60(12): pp. 1253-1260. Available : http://eprints.qut.edu.au/13239/1/13239.pdf

Shapiro, S.S., \& Wilk, M.B., (1965). An analysis of variance test for normality (complete samples). Biometrika, 52(3/4), 591-611 
Shim, S, \& Kotsiopulos, A. (1993). A typology of apparel shopping orientation segments among female consumers, Clothing and Textiles Research Journal 12(1):73-85

Sinha, P.K., Banerjee, A. and Uniyal, D.P., (2002) Deciding where to buy: Store choice behaviour of Indian shoppers. Vikalpa, 27 (2). pp. 13-28. Available: http://www.vikalpa.com/pdf/articles/2002/2002_apr_jun_13_28.pdf

Smith, R.A., (2008) Fashion Online: Retailers Tackle the Gender Gap. Wall Street Journal. pp. 1-2. Available: http://proquest.umi.com/pqdweb?did=1444807621\&sid=4\&Fmt=3\&clientId=30060\&RQT =309\&VName=PQD

Steenkamp, J.E.M. and Hofstede, F. (2002), "International market segmentation: issues and perspectives", International Journal of Research in Marketing, Vol. 19 No. 3, pp. 185-213.

Stone, G.P., (1954). City shoppers and urban identification: Observation on the social psychology of city life. American Journal of Sociology 60(1):36-45

Stone, G. P., (1962). Appearance and the self. In A. M. Rose (Ed.), Human behavior and social processes: An interactionist approach (pp.86-118). New York: Houghton Mifflin.

Wilson, J.D. \& MacGillivray, M.S.(1998), "Self-perceived influence of family, friends and media on adolescents clothing choice," Family and Consumer Sciences research Journal, Thousand Oaks, June www.statistics.gov.com.my

Yarrow, K. and O’Donnell, J., (2009) Gen BuY: How tweens, teens, and twenty-something's are revolutionizing retail. San Francisco, Jossey-Bass.

Zhang, Z., Li, Y., Gong, C. and Wu, H., (2002). Casual wear product attributes: A Chinese consumers" perspective. Journal of Fashion Marketing and Management, 6 (1).pp.53-62.

Available:http://www.emeraldinsight.com/Insight/ViewContentServlet?Filename=Publishe

d/EmeraldFullTextArticle/Articles/2840060105.html

http://www.ibef.org/download/Retail50112.pdf

http://www.mckinsey.com/insights/consumer_and_retail/how_half_the_world_shops_apparel_in_brazil_china_an d_india 